\title{
Serum GH response to pharmacological stimuli and physical exercise in two siblings with two new inactivating mutations in the GH-releasing hormone receptor gene
}

\author{
Roberto Salvatori, Xiaoguang Fan, Johannes D Veldhuis ${ }^{1}$ and Robert Couch $^{2}$ \\ Division of Endocrinology, Department of Medicine and The Ilyssa Center for Molecular and Cellular Endocrinology, The Johns Hopkins University School \\ of Medicine, 1830 East Monument Street no. 333, Baltimore, Maryland 21287, USA, ${ }^{1}$ Division of Endocrinology, Department of Medicine, \\ University of Virginia School of Medicine, Charlottesville, Virginia 22908, USA and ${ }^{2}$ Department of Pediatrics, University of Alberta, Edmonton, Alberta \\ T6G 2R7C, Canada \\ (Correspondence should be addressed to Roberto Salvatori; Email: salvator@jhmi.edu)
}

\begin{abstract}
Objective: Inactivating mutations of the GH-releasing hormone receptor (GHRHR) gene (GHRHR) cause familial isolated GH deficiency (IGHD) type IB. The GH response to physical exercise (PE) in patients lacking GHRHR has never been studied. We hypothesized that subjects lacking functional GHRHR may be a model to study GH response to PE.

Design: We have analyzed peripheral genomic DNA of a family with two sibs affected by IGHD IB for mutations in the GHRHR, studied the patients' GH response to different GH secretagogues and to PE, and examined the morphology of their pituitary gland by magnetic resonance imaging (MRI).

Methods: The GHRHR was analyzed by direct sequencing of the 13 exons, intron-exon boundaries, and of the proximal $327 \mathrm{bp}$ of the promoter region in the index case. The patients' GH response to GHRH and standardized PE was studied twice, using a GH ultrasensitive assay in the second round of testing.

Results: Both subjects were compound heterozygotes for two previously undescribed mutations in the GHRHR that are predicted to cause complete lack of functional GHRHR protein: a nonsense mutation in codon $43(\mathrm{Q} 43 \mathrm{X})$, and a splice mutation at the beginning of intron 3 (IVS3 $+1 \mathrm{G} \rightarrow \mathrm{A}$ ). MRI showed hypoplasia of their anterior pituitaries. Both subjects had a small but detectable increase in serum GH after maximal PE.

Conclusions: GHRHR mutations need to be considered in IGHD IB patients even in the absence of parental consanguinity, and patients lacking GHRHR may provide a model to study the mechanism by which PE influences GH secretion.
\end{abstract}

European Journal of Endocrinology 147 591-596

\section{Introduction}

Pituitary secretion of growth hormone (GH) and somatotroph cell proliferation are under hypothalamic control. They are stimulated by GH-releasing hormone (GHRH) and inhibited by somatostatin (1). These two hormones act on the somatotroph cells by binding to specific cell surface receptors, which have opposite effects on intracellular cAMP production. The physiological role of ghrelin (recently identified from the rat stomach), the natural ligand for the GH-releasing peptide (GHRP) receptor, is not yet well defined (2).

Isolated GH deficiency (IGHD) type IB, the most prevalent form of familial IGHD, is transmitted as an autosomal recessive trait (3). Unique mutations in the gene encoding the GHRH receptor (GHRHR) (GHRHR, Online Mendelian Inheritance in Man gene no.
139191) have been recently described by others and us in kindreds with IGHD IB (3-11). Although most commonly GHRHR mutations have been reported in families in which the homozygous affected subjects had consanguineous parents, we have previously described three kindreds in which affected subjects are compound heterozygotes for different mutations in this gene $(7,8,11)$.

Patients with two faulty GHRHR alleles have severe IGHD, and their serum GH response to conventional GH stimulation tests is frankly subnormal $(3-11)$. However, their GH response to physical exercise (PE) has never been studied.

We report here that the two affected subjects from a newly identified IGHD IB family are compound heterozygotes for two new null mutations in the GHRHR, both predicted to cause completely non-functional or absent 
receptor proteins. We describe clinical and molecular findings in these subjects, their pituitary imaging and their GH response to chemical stimuli and to maximal PE.

\section{Patients and methods}

\section{Patients}

Two brothers presented to medical attention in 1992 for evaluation of short stature. They were the products of normal uncomplicated pregnancies that ended in spontaneous deliveries from non-blood related, normal-stature parents (father $175 \mathrm{~cm}$, mother $171 \mathrm{~cm}$, by report). There were no reports of neonatal hypoglycemia. The pedigree of the family is shown in Fig. 1.

At presentation, subject II-1 was 11 years old, measured $108.2 \mathrm{~cm}$ ( -5.5 SDS), and had a bone age (calculated via Greulich and Pyle atlas) of 8 years. Subject II-2 was 8 years and 9 months old, measured $101.1 \mathrm{~cm}(-5.5$ SDS) and had a bone age of 6 years. Both patients were pre-pubertal (Tanner 1 stage). Physical examination was normal, except of short stature. They both had normal hemoglobin levels, blood chemistries and thyroid function tests. They had normal prolactin and normal thyrotrophin (TSH) response to thyrotrophin-releasing hormone (TRH; data not shown). Serum insulin-like growth factor-I (IGF-I) was low in both subjects: $20 \mu \mathrm{g} / \mathrm{l}$ (age-appropriate normal value (NV) 110-565) in subject II-1 and $16 \mu \mathrm{g} / \mathrm{l}$ (NV 77-437) in subject II-2.

Their GH secretion was evaluated at the time of presentation by sleep test (blood drawn every $30 \mathrm{~min}$ for $10 \mathrm{~h}$ during night-time sleep), arginine infusion $(0.5 \mathrm{~g} / \mathrm{kg}$ intravenously over $30 \mathrm{~min})$, and L-dopa $\left(0.5 \mathrm{mg} / 1.73 \mathrm{~m}^{2}\right.$ orally) plus propanolol $(0.75 \mathrm{mg} / \mathrm{kg}$ orally). Serum GH levels were at all points below the sensitivity of the assay used at that time $(0.1 \mu \mathrm{g} / \mathrm{l})$, consistent with severe GH deficiency (GHD). Both

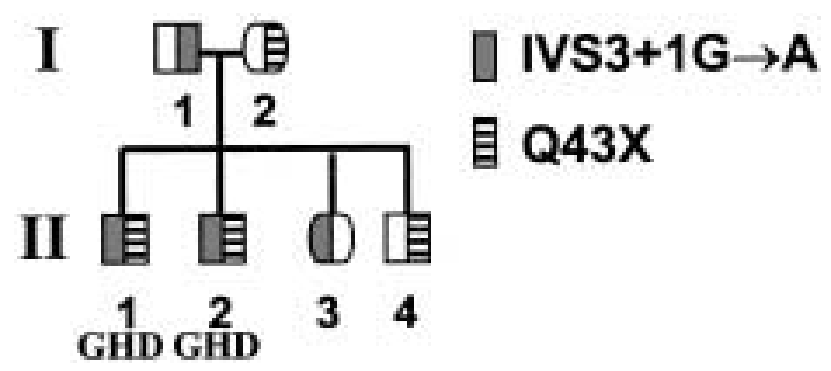

Figure 1 Pedigree of the family with mutations in the GHRHR. Squares denote male family members, ovals female family members. The white half symbols represent the wild-type allele; the gray half symbols represent the IVS $3+1 \mathrm{G} \rightarrow \mathrm{A}$ mutation, and the horizontal lines half symbols represent the Q43X mutation. subjects were treated with GH replacement therapy $(0.18 \mathrm{mg} / \mathrm{kg}$ per week), with good growth response. They underwent spontaneous puberty, and attained adult stature of $170.5 \mathrm{~cm}$ (subject II-1) and $166.8 \mathrm{~cm}$ (subject II-2). At adult age, 1 year after discontinuing exogenous GH therapy, subject II-1 had unmeasurable serum IGF-I $(<15 \mu \mathrm{g} / \mathrm{l}, \mathrm{NV} 182-780)$ and low IGF-binding protein-3 (1.0 mg/l, NV 2.5-4.8), confirming persistence of severe GHD. These tests were not done in subject II-2.

The subjects gave informed written consent for the studies described below. The protocol was approved by the local ethics committee.

\section{Testing of GH secretion}

GH secretion in both subjects (II-1 and II-2) was re-studied after they reached adult ages (20 and 18 years old respectively). They were both at Tanner stage 5 of sexual development and had normal body mass index: 25.0 and 26.6 respectively. Neither of them had taken exogenous $\mathrm{GH}$ for at least 1 month. They underwent arginine, GHRH and PE stimulation tests. Each GH test was performed on separate days after an overnight fast. An indwelling catheter was placed in a forearm vein. Clonidine was administered orally $\left(0.15 \mathrm{mg} / \mathrm{m}^{2}\right)$ and blood samples were obtained at 0, 30, 60, 90 and $120 \mathrm{~min}$. Arginine was administered as an intravenous infusion at the dose of $30 \mathrm{~g}$ over $30 \mathrm{~min}$ and blood samples were obtained at $0,15,30,45,60$ and $90 \mathrm{~min}$. 1-29 GHRH (Geref, Serono Norwell, MA, USA) $1 \mu \mathrm{g} / \mathrm{kg}$ was administered as an i.v. bolus and blood samples were obtained at $0,15,30,45,60$, 90 and $120 \mathrm{~min}$.

A standardized bicycle protocol was used for exercise testing (12). An indwelling catheter was placed in the forearm and blood was drawn for baseline GH. After subjects warmed up for $3 \mathrm{~min}$, resistance was increased to keep heart rate at or above $70 \%$ of predicted maximum work rate. Both subjects cycled for more than $15 \mathrm{~min}$ to exhaustion. Blood samples were obtained immediately at the end of exercise, and 5, 10 and 20 min later.

Serum was immediately separated, and kept frozen until assayed. GH was assayed via commercially available immunoradiometric assay (Immulite Growth Hormone, DPC, Los Angeles, CA, USA) with a sensitivity limit of $0.05 \mu \mathrm{g} / \mathrm{l}$.

Several months later, the subjects underwent repeated GHRH and PE testing (on different days), following the same protocol described above. For this round of tests, serum GH was measured with an ultrasensitive assay, with a detection limit of $0.002 \mu \mathrm{g} / \mathrm{l}$, intra-assay coefficients of variation of $8.5 \%$, and inter-assay coefficients of variation of $4.6 \%$ $(13-15)$. 


\section{Amplification of the GHRHR and mutation detection}

Genomic DNA was extracted from peripheral blood leukocytes by standard techniques. The 13 exons and the corresponding intron-exon boundaries and the proximal 327 bases of the promoter of the GHRHR from the index case (II-1) were individually amplified via PCR as in previous studies $(6,7)$.

PCR products were separated by electrophoresis through $8 \%$ acrylamide gels, and bands were isolated and sequenced directly. Sequencing was performed using the Amersham Thermo-Sequenase Cycle Sequencing Kit (Amersham Pharmacia Biotech, Piscataway, NJ, USA). After the identification of a mutation in the index patient, all other members of the family were genotyped via direct sequencing of the appropriate gene regions.

We then tested whether the newly identified mutations (see below) alter the migration pattern of the respective amplicon (amplified with one of the primers containing a $5^{\prime}$ GC-rich 40-base tail) when analyzed by denaturing gradient gel electrophoresis (DGGE) $(16,17)$. As they both did, we used DGGE to test the prevalence of the newly discovered changes in a commercial panel of genomic DNAs from 44 normal subjects ( 88 chromosomes) obtained from the DNA Polymorphism Discovery Resource, which includes DNA from anonymous unrelated individuals with diverse ethnicity (18).

\section{Results}

\section{Mutations identification}

We found two heterozygous nucleotide changes in the GHRHR of the two affected boys when compared with the normal sequence (19). One is a $\mathrm{C}$ to $\mathrm{T}$ transition that results in substitution of glutamine (CAA) in position 43 with a stop codon (TAA) (Q43X) (Fig. 2), which was also found in heterozygous fashion in the subjects' mother and in one of the normal stature siblings (II-4).

The second mutation, a $\mathrm{G}$ to $\mathrm{A}$ transition located in the splice donor site at the beginning of intron 3 (IVS3 $+1 \mathrm{G} \rightarrow \mathrm{A}$ ) (Fig. 3), was also found in heterozygous fashion in the subjects' father and in the other normal sibling (II-3).

The G nucleotide of the splice donor site (GT) is conserved in $100 \%$ of mammalian genes and mutations are consistently associated with a non-functional allele (20). The IVS $3+1 \mathrm{G} \rightarrow$ A mutation is predicted to cause the retention of part or all of intron 3 and a severe alteration of protein structure. No potential cryptic splice site has been identified downstream of the normal donor splice site, and an in-frame TAG stop codon is located 123 nucleotides from the end of the exon 3 coding region.

Neither of these two new mutations was found in 88 normal chromosomes from the Polymorphism Discovery Resource (18), screened by DGGE.

\section{GH testing}

In both subjects, GH remained below the assay sensitivity at all points during arginine, clonidine and GHRH testing when tested with an immunoradiometric assay with a detection limit of $0.05 \mu \mathrm{g} / \mathrm{l}$. By contrast, PE caused a detectable increase in GH secretion in both subjects at all points after exercise completion (Table 1, upper rows). This increase is significantly lower than the increase reported for normal adult subjects (peak GH after $\mathrm{PE}=7.8+1.3 \mu \mathrm{g} / \mathrm{l}$ ) (21).

We then repeated GHRH and PE testing, and measured the GH response using an ultrasensitive $\mathrm{GH}$ assay. Both subjects' serum GH was confirmed to be above $0.05 \mu \mathrm{g} / \mathrm{l}$ at all points after PE. However, although in both subjects the absolute GH peak after exercise was higher than after GHRH stimulation, the

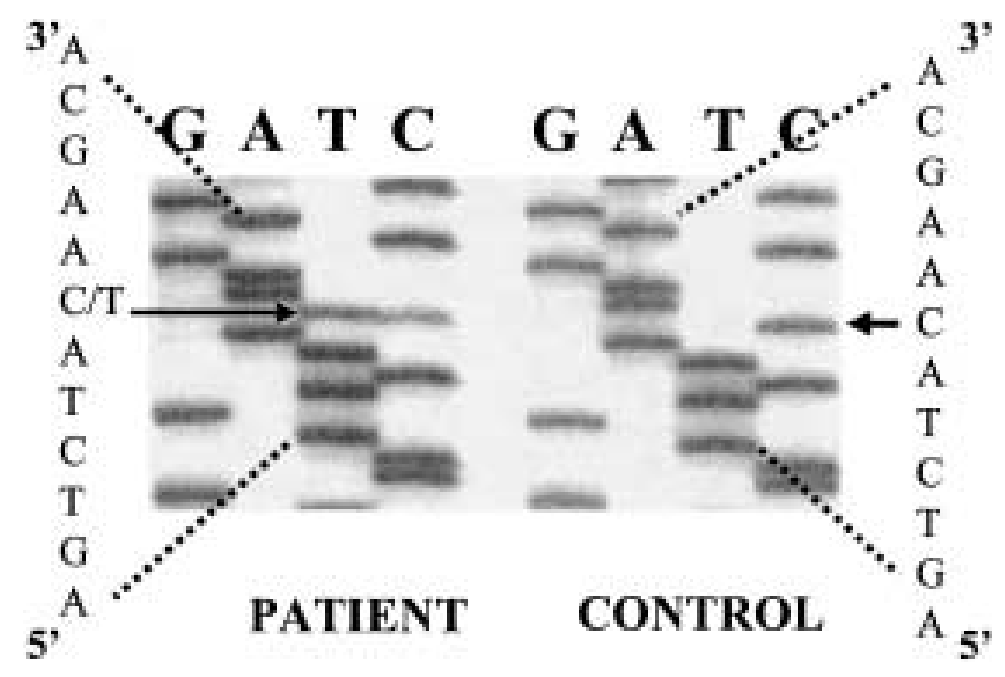

Figure 2 Sequence analysis of a portion of exon 2 of the GHRHR from genomic DNA of the index patient (PATIENT). The normal sequence (CONTROL) is from an unrelated normal subject. The heterozygous $\mathrm{C}$ to $\mathrm{T}$ transition is indicated by the arrow. 


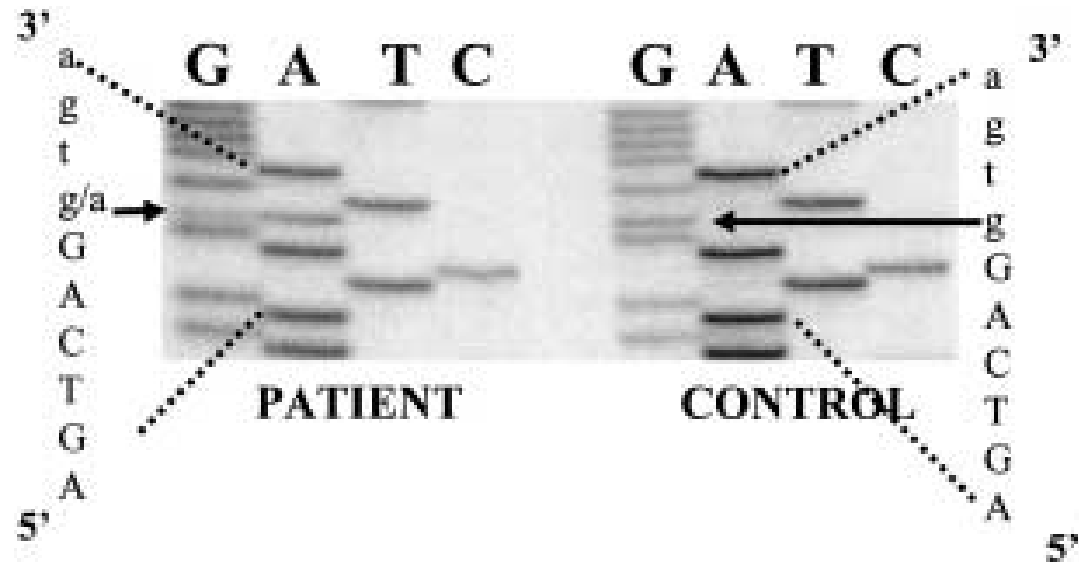

Figure 3 Sequence analysis of a portion of exon 3-intron 3 junction of the GHRHR from genomic DNA of the index patient (PATIENT). The normal sequence (CONTROL) is from an unrelated normal subject. The heterozygous $G$ to $A$ transition is indicated by the arrow. The exon 3 sequence is shown in capital letters, and the intron 3 sequence in lower case letters. difference between the two stimuli was much less evident, with individual peak $\mathrm{GH}$ levels that for patient II-2 were quite similar during the two tests (Table 1 , lower rows).

\section{Radiological evaluation}

Magnetic resonance imaging (MRI) of the sellar region in both patients revealed hypoplastic anterior pituitary glands (2.5 and $3 \mathrm{~mm}$ in height respectively), similar to what has been described in patients with other homozygous null mutations of the $\operatorname{GHRHR}(7,11$, 22, 23).

\section{Discussion}

Mutations in the GHRHR are being recognized with increasing frequency in patients with familial IGHD. So far, one nonsense, five missense, two splice mutations, two small deletions (one of them with possible dominant negative effect), and a promoter mutation have been reported (3-11). In most families, parents of affected subjects are either consanguineous or are connected by common ancestry even when they live in different geographical areas (24). Our two patients have no family history of consanguinity. Accordingly, they are compound heterozygotes for two different, previously undescribed, mutations in the GHRHR. The first one is a nonsense mutation in exon $2(\mathrm{Q} 43 \mathrm{X})$, which, if mRNA is translated, would cause the generation of a severely truncated protein (only containing a small fragment of the extracellular domain). The second one is a splice site mutation $($ IVS $3+1 G \rightarrow A)$ at the beginning of intron 3 . The IVS $3+1 \mathrm{G} \rightarrow \mathrm{A}$ mutation alters the first base of the splice donor site (GT), which is conserved in $100 \%$ of mammalian genes (20). As a consequence, it is predicted that part or the entire intron 3 is retained in the mature mRNA. An in-frame stop codon localized in intron 3 (123 bases from the mutation) would cause protein truncation. Although a GHRHR splice variant lacking exon 1-3 coding sequences has been described in prostate cancer cells and in a pituitary adenoma (25), it is unlikely that this variant would be expressed in the patient's pituitary, as mRNAs containing premature stop codons are likely to be degraded by nonsense-mediated mRNA decay (26). Therefore, both of these two mutations are likely to cause total absence of the GHRHR protein. The absence of either mutation from 88 normal chromosomes demonstrates that they are not highly prevalent in the general population.

Table 1 Serum GH response (in $\mu \mathrm{g} / \mathrm{l}$ ) to PE and GHRH in two sibs (II-1 and II-2) with mutated GHRHR analyzed by an IRMA with a sensitivity limit of $0.05 \mu \mathrm{g} / \mathrm{l}$ (upper rows), and by a chemiluminescence ultrasensitive assay (CLU) with a sensitivity limit of $0.002 \mu \mathrm{g} / \mathrm{l}$ (lower rows). Pre = pre-exercise; End = end of maximal exercise, Each assay relates to tests done on separate days.

\begin{tabular}{|c|c|c|c|c|c|c|c|c|c|c|c|c|}
\hline & \multicolumn{5}{|c|}{ PE } & \multicolumn{7}{|c|}{ GHRH } \\
\hline & Pre & End & $5 \mathrm{~min}$ & $10 \mathrm{~min}$ & $20 \min$ & $0 \min$ & $15 \mathrm{~min}$ & $30 \mathrm{~min}$ & $45 \min$ & $60 \mathrm{~min}$ & $90 \min$ & $120 \mathrm{~min}$ \\
\hline \multicolumn{13}{|c|}{ IRMA } \\
\hline$\|-1$ & $<0.05$ & 0.14 & 0.13 & 0.11 & 0.08 & $<0.05$ & $<0.05$ & $<0.05$ & $<0.05$ & $<0.05$ & $<0.05$ & $<0.05$ \\
\hline $\begin{array}{l}\text { II-2 } \\
\text { CLU }\end{array}$ & $<0.05$ & 0.26 & 0.36 & 0.26 & 0.22 & $<0.05$ & $<0.05$ & $<0.05$ & $<0.05$ & $<0.05$ & $<0.05$ & $<0.05$ \\
\hline$\|-1$ & 0.036 & 0.112 & 0.106 & 0.088 & 0.060 & 0.022 & 0.022 & 0.023 & 0.024 & 0.033 & 0.077 & 0.038 \\
\hline II-2 & 0.007 & 0.109 & 0.132 & 0.130 & 0.101 & 0.061 & 0.027 & 0.014 & 0.008 & 0.006 & 0.088 & 0.104 \\
\hline
\end{tabular}


The phenotype in our patients closely resembles previously described patients with different null GHRHR mutations, including severe GHD and MRI evidence of anterior pituitary hypoplasia, likely due to reduced somatotroph cell mass similar to findings in the little mouse, a murine model of GHRHR gene mutation (27).

We have previously reported that two sibs who are compound heterozygotes for two missense mutations in the GHRHR presented a notable GH increases after PE (peak GH 14.3 and $13.9 \mu \mathrm{g} / \mathrm{l}$ ), despite frankly subnormal GH responses to insulin-induced hypoglycemia (peak GH 3.8 and $2.3 \mu \mathrm{g} / \mathrm{l}$ despite frank hypoglycemia) and absent night-time GH peaks (7). However, these patients were studied in the 1970s, using an old polyclonal GH radioimmunological assay with limited sensitivity and specificity (28), and the exercise test was not standardized. Furthermore, missense mutations may allow partial residual receptor function. Conversely, the patients described in this report are predicted to completely lack functional GHRHR protein. Therefore, the analysis of their GH response to standardized PE by a sensitive modern assay may help to shed some light on the mechanism by which PE causes GH secretion, as it has been speculated that PE may act by removing somatostatin inhibition on somatotroph cells rather than by increasing hypothalamic GHRH secretion (29-31). The limitation of this model is the severely decreased somatotroph mass that greatly reduces the potential of their pituitaries of producing GH. However, patients lacking functional GHRHR have detectable $\mathrm{GH}$ pulses and a detectable rise in serum GH to acute stimulation with the GH secretagogue GHRP-2, proving that their somatotrophs (although reduced in number) are properly differentiated and able to respond to stimuli that may, at least in part, not depend on an intact GHRH pathway $(10,32,33)$.

We found that, using an IRMA assay with a sensitivity of $0.05 \mu \mathrm{g} / \mathrm{l}$, serum $\mathrm{GH}$ levels were below detection at all points in both patients after GHRH or arginine or clonidine. These three tests sum to a total of 15 poststimulus points per patient, although it must be kept in mind that clonidine is a notoriously poor $\mathrm{GH}$ stimulant in adults (34). By contrast, GH was detectable (albeit low) at all four points after maximal PE. When we sought to confirm these findings by repeating the GHRH and PE testing measuring GH by ultrasensitive chemiluminescence assay, we found that the GH was confirmed to be above $0.05 \mu \mathrm{g} / \mathrm{l}$ at all points after PE, and the absolute $\mathrm{GH}$ peaks were higher after PE than after GHRH (0.112 vs 0.077 and 0.132 vs 0.104 respectively). However, the difference between response to PE and GHRH was not fully confirmed. In the repeated GHRH testing, both subjects had one or more time points $(90 \mathrm{~min}$ for II-1, baseline, $90 \mathrm{~min}$ and $120 \mathrm{~min}$ for II-2) that were above $0.05 \mu \mathrm{g} / \mathrm{l}$, partially invalidating the results of the less sensitive assay. In addition, as the peak after GHRH in subject
II-2 is reached at the last time point (120 min), we cannot rule out the possibility that, had we continued the test for a longer time, his serum GH level would have further increased. It is likely that that these 'post-GHRH' peaks are actually unrelated to GHRH injection, and are just an expression of spontaneous GH pulsatility $(10,33)$. This is less likely for the peaks reached after exercise, as the peaks' profiles are very similar for the two patients, and are sustained for several minutes after completion of PE.

Arginine is believed to act by removing somatostatin's influence on somatotroph cells rather than stimulating GHRH secretion (35). No GH response to arginine (measured by IRMA) was detected in our patients, arguing against the hypothesis that $\mathrm{PE}$ works via the same pathway. Regrettably, no sera are available to repeat the measurements using the ultrasensitive assay.

Although these results do not allow us to draw any definitive conclusion, this initial observation creates the rationale for studying $\mathrm{GH}$ response to $\mathrm{PE}$ in larger kindreds with mutated GHRHR, such as the ones from Brazil and Pakistan $(5,6)$, where the high number of subjects may allow us to determine if any difference in $\mathrm{GH}$ secretion after $\mathrm{PE}$ and chemical secretagogues is real.

In conclusion, we have described two brothers with IGHD caused by compound heterozygosity for two new null mutations in the GHRHR. These findings indicate that faulty GHRHR alleles may be quite prevalent, that GHRHR mutations need to be considered in IGHD IB patients even in the absence of parental consanguinity, and suggest that patients lacking functional GHRHR may provide a natural model to study the mechanism by which PE influences GH secretion.

\section{Acknowledgements}

We wish to thank the patients who volunteered their time for the studies. This work was supported by NIH-NCRR GCRC-CAP award 3 M01 RR000052$38 \mathrm{~S} 1$ (R S), and by a grant from the Genentech Center for Clinical Research and Education (R S).

\section{References}

1 Muller EE, Locatelli V \& Cocchi D. Neuroendocrine control of growth hormone secretion. Physiology Reviews $1999 \quad 79$ 511-607.

2 Kojima M, Hosoda H, Date Y, Kakazato M, Matsuo H \& Kangawa K. Ghrelin is a growth hormone-releasing acylated peptide from stomach. Nature $1999 \mathbf{4 0 2} 656-660$.

3 Cogan JD \& Phillips JA III. Growth disorders caused by genetic defects in the growth hormone pathway $\mathrm{GH}$ deficiency. In Advances in Pediatrics, pp 337-361. Eds LA Barness, G Morron III, AM Rudolph, DC De Vivo, MM Kabacl \& WW Tunnessen Jr. Mosby: St Louis, 1998.

4 Wajnrajch MP, Gertner JM, Harbison MD, Chua SC Jr \& Leibel RL. Nonsense mutation in the human growth hormone-releasing 
hormone receptor causes growth failure analogous to the little (lit) mouse. Nature Genetics 199612 88-90.

5 Maheshwari HG, Silverman BL, Dupuis J \& Baumann G. Phenotype and genetic analysis of a syndrome caused by an inactivating mutation in the growth hormone-releasing hormone receptor: dwarfism of Sindh. Journal of Clinical Endocrinology and Metabolism $1998 \mathbf{8 3}$ 4065-4074.

6 Salvatori R, Hayashida CY, Aguilar-Oliveira MH, Phillips JA 3rd, Souza AH, Gondo RG et al. Familial dwarfism due to a novel mutation in the growth hormone-releasing hormone receptor. Journal of Clinical Endocrinology and Metabolism $1999 \mathbf{8 4}$ 917-923.

7 Salvatori R, Fan X, Phillips JA III, Espigares-Martin R, Martin De Lara I, Freeman KL et al. Three new mutations in the gene for the growth hormone $(\mathrm{GH})$-releasing hormone receptor in familial isolated GH deficiency type IB. Journal of Clinical Endocrinology and Metabolism 2001 86 273-279.

8 Salvatori R, Fan X, Phillips JA III, Prince M \& Levine MA. Isolated growth hormone $(\mathrm{GH})$ deficiency due to compound heterozygosity for 2 new mutations in the GH-releasing hormone receptor gene. Clinical Endocrinology $20015 \mathbf{5 4} 681-687$.

9 Horikawa R, Fujiita K, Nakajima R, Gaylinn BD \& Tanaka T. A novel growth hormone-releasing hormone (GHRH) receptor mutation as a cause for isolated GH deficiency in Japanese boy with severe short stature. Proceedings of the 82nd Meeting of the Endocrine Society, Toronto, Canada 2000 Abstract 1995.

10 Roelfsema F, Biermasz NR, Veldman RG, Veldhuis JD, Frolich M, Stokvis-Brantsma WH et al. Growth hormone (GH) secretion in patients with an inactivating defect of the GH-releasing hormone (GHRH) receptor is pulsatile: evidence for a role for non-GHRH inputs into the generation of $\mathrm{GH}$ pulses. Journal of Clinical Endocrinology and Metabolism 200186 2459-2464.

11 Salvatori R, Fan X, Mullis PE, Haile A \& Levine MA. Decreased expression of the GHRH receptor gene due to a mutation in a Pit-1 binding site. Molecular Endocrinology $200216450-458$.

12 Seip RL, Weltman A, Goodman D \& Rogol AD. Clinical utility of cycle exercise for the clinical assessment of growth hormone release in children. American Journal of Diseases in Childhood $1990144998-1000$.

13 Iranmanesh A, Grisso B \& Veldhuis JD. Low basal and persistent pulsatile growth hormone secretion are revealed in normal and hyposomatotropic men studied with a new ultrasensitive chemiluminescence assay. Journal of Clinical Endocrinology and Metabolism 199478 526-535.

14 Chapman IM, Hartman ML, Straume M, Johnson ML, Veldhuis JD \& Thorner MO. Enhanced sensitivity growth hormone $(\mathrm{GH})$ chemiluminescence assay reveals lower postglucose nadir $\mathrm{GH}$ concentrations in men than women. Journal of Clinical Endocrinology and Metabolism $1994 \mathbf{7 8} 1312-1319$.

15 Veldhuis JD, Liem AY, South S, Weltman A, Weltman J, Clemmons DA et al. Differential impact of age, sex steroid hormones and obesity on basal versus pulsatile growth hormone secretion in men as assessed in an ultrasensitive chemiluminescence assay. Journal of Clinical Endocrinology and Metabolism $1995 \mathbf{8 0}$ 3209-3222.

16 Miller KM, Ming TJ, Schulze AD \& Withler RE. Denaturing gradient gel electrophoresis (DGGE): a rapid and sensitive technique to screen nucleotide sequence variation in populations. Biotechniques 199927 1016-1018.

17 Sheffield VC, Cox DR, Lerman LS \& Myers RM. Attachment of a 40-base-pair G + C-rich sequence (G-C clamp) to genomic DNA fragments by the polymerase chain reaction results in improved detection of single-base changes. PNAS $198986232-236$.

18 Collins FS, Brooks LD \& Chakravarti A. A DNA polymorphism discovery resource for research on human genetic variation. Genomic Research 19988 1229-1231.

19 Gaylinn BD, Harrison JK, Zysk JR, Lyons CE, Lynch KR \& Thorner MO. Molecular cloning and expression of human anterior pituitary receptor for growth hormone-releasing hormone. Molecular Endocrinology 1993 7 77-84.
20 Horowitz DS \& Krainer AR. Mechanism for selecting $5^{\prime}$ splice sites in mammalian pre-mRNA splicing. Trends in Genetics 199410 100-105.

21 Cappa M, Grossi A, Benedetti S, Drago F, Loche S \& Ghigo E. Effect of the enhancement of cholinergic tone by pyridostigmine on the exercise-induced growth hormone release in man. Journal of Endocrinological Investigation 199316 421-424.

22 Netchine I, Talon P, Dastot F, Vitaux F, Goosens M \& Amselem S. Extensive phenotypic analysis of a family with growth hormone $(\mathrm{GH})$ deficiency caused by a mutation in the GH-releasing hormone receptor gene. Journal of Clinical Endocrinology and Metabolism $1998 \mathbf{8 3} 432-436$.

23 Murray RA, Maheshwari HG, Russell EJ \& Baumann G. Pituitary hypoplasia in patients with a mutation in the growth hormone-releasing hormone receptor gene. American Journal of Neuroradiology 200021 685-689.

24 Wajnrajch MP, Gertner MJ, Harbison MD, Netchine I, Maheshwari HG \& Baumann G et al. Haplotype analysis of three kindreds with an identical (E72X) mutation in the growth hormone releasing hormone receptor gene. Proceedings of the 81st Meeting of the Endocrine Society, San Diego, CA 1999 Abstract P2-289.

25 Rekasi Z, Czompoly T, Schally AV \& Halmos G. Isolation and sequencing of cDNAs for splice variants of growth hormonereleasing hormone receptors from human cancers. PNAS 2000 $9710561-10566$.

26 Frischmeyer PA \& Dietz HC. Nonsense-mediated mRNA decay in health and disease. Human Molecular Genetics 19998 1893-1900.

27 Lin S-C, Lin CR, Gukovski I, Lusis AJ, Sawchenko PE \& Rosenfeld MG. Molecular basis of the little mouse phenotype and implications for cell type-specific growth. Nature $1993 \mathbf{3 6 4} 208-213$.

28 L'Hermite-Baleriaux M, Copinschi G \& Van Cauter E. Growth hormone assays: early to latest test generation compared. Clinical Chemistry $1996 \mathbf{4 2} 1789-1795$.

29 Di Luigi L, Conti FG, Casini A, Guidetti L, Zezze G, Pigozzi F et al. Growth hormone and insulin-like growth factor I responses to moderate submaximal acute physical exercise in man: effects of octreotide, a somatostatin analogue, administration. International Journal of Sports Medicine 199718 257-263.

30 Casanueva FF, Villanueva L, Cabranes JA, Cabezas-Cerrato J \& Fernandez-Cruz A. Cholinergic mediation of growth hormone secretion elicited by arginine, clonidine, and physical exercise. Journal of Clinical Endocrinology and Metabolism $1984 \mathbf{5 9}$ 526-530.

31 Cappa M, Bizzarri C, Martinez C, Porzio O, Giannone G, Turchetta A et al. Neuroregulation of growth hormone during exercise in children. International Journal of Sports Medicine 200021 (Suppl 2) 125-128.

32 Gondo RG, Aguiar-Oliveira MH, Hayashida CY, Toledo SP, Abelin $\mathrm{N}$, Levine MA et al. Growth hormone-releasing peptide-2 stimulates GH secretion in GH-deficient patients with mutated GH-releasing hormone receptor. Journal of Clinical Endocrinology and Metabolism 200186 3279-3283.

33 Maheshwari HG, Pezzoli SS, Rahim A, Shalet SM, Thorner MO \& Baumann G. Pulsatile growth hormone secretion persists in genetic growth hormone-releasing hormone resistance. American Journal of Physiology: Endocrinology and Metabolism $2002 \mathbf{2 8 2}$ E943-E951.

34 Aimaretti G, Baffoni C, DiVito L, Bellone S, Grottoli S, Maccario M et al. Comparisons among old and new provocative tests of $\mathrm{GH}$ secretion in 178 normal adults. European Journal of Endocrinology $2000142347-352$.

35 Ghigo E. Neurotransmitter control of growth hormone secretion. In Regulation of Growth Hormone and Somatic Growth, pp 103-136. Ed. LF de la Cruz. Amsterdam: Elsevier, 1992.

Received 3 April 2002

Accepted 29 May 2002 